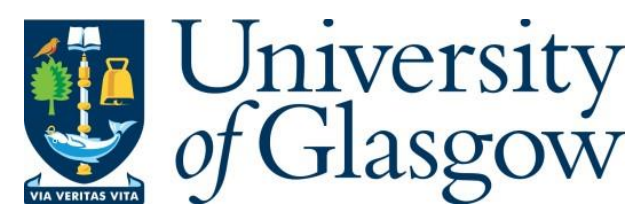

Steel, C. (2018) Roman citizenship between law and practice. In: Ellis, S. G. (ed.)

Enfranchising Ireland? Citizenship, Identity and State. Royal Irish Academy: Dublin, pp. 7-18. ISBN 9781908997845.

There may be differences between this version and the published version. You are advised to consult the publisher's version if you wish to cite from it.

http://eprints.gla.ac.uk/161306/

Deposited on: 26 April 2018

Enlighten - Research publications by members of the University of Glasgow http://eprints.gla.ac.uk 


\title{
1. Roman citizenship between law and practice
}

\author{
Catherine Steel
}

\section{Roman citizenship in its ancient context}

The idea of citizenship is one of the key legacies of classical antiquity: a status that combines membership of a community, participation in its political processes and undifferentiated access to and protection within a shared legal framework. Among the different models of citizenship afforded by different city-states, that of Rome stands out, both because of the importance of Rome among ancient Mediterranean communities - at least from the third century ВС onwardsand because of its function as a model within Western political thought. Furthermore, there were a number of highly distinctive features in its handling of citizenship which marked it out among ancient city-states.

Rome was unusually willing among ancient city-states to give citizenship to non-citizens. ${ }^{1}$ It also separated the status of citizenship from the place of habitation, and, as a result of Rome's political reach across Italy, and the mobility of its citizens in pursuit of military and economic goals, many Roman citizens were based outside Rome itself centuries before all free inhabitants of the Roman empire became Roman citizens, in $\mathrm{AD} 212 .^{2}$ Its idea of citizenship did not appear to relate directly to ideas of biological 
kinship or ethnic identity; literally anyone could be a Roman, and as a result of the connection between the manumission of slaves and enfranchisement, and the heritability of citizenship, the Roman citizen body was extremely heterogeneous. Inclusivity as an aspect of community membership was embedded in the foundational stories of Rome as a political entity even before the establishment of the Republic, with the very existence of the city depending upon the incomers whom Romulus, the first king of Rome, welcomed in his asylum. This society was sustained because of the willingness of the first generation of Roman men to marry foreigners, as recorded in the story of the rape of the Sabine women. ${ }^{3}$ Women could be citizens; and Roman citizenship was closely linked to ideas of equality, both in terms of equality before the law and as a guarantee of rights to participate in political processes. The nature of Roman citizenship was identified as an element in its extraordinary success: its willingness to enfranchise non-Romans was the basis of its extraordinary resources in manpower, which in turn contributed to Rome's emergence as the dominant Mediterranean power during the second century BC. Late in the third century BC, Philip V of Macedon wrote to the city of Larisa and cited Rome as evidence for the benefits of extending access to citizenship: 'they receive into their polity even slaves, when they free them, and give them a share of magistracies, and as a result have increased not only their ancestral homeland but have sent out colonies to almost seventy places'. ${ }^{4}$

Inclusiveness, the rejection of ethnic determinism and the transcending of geographical limitations are attractive features to many contemporary commentators and it is unsurprising that citizenship plays a part in a wave of recent positive interpretations of Rome as a political community. Indeed, a striking feature of the last decade of research in Roman history has been its positive assessment of Roman political practice, from which Rome emerges as a model of civic deliberation and the rule of law. Thus, Joy Connolly in two monographs on political literature written during the Roman Republic has set out a powerful argument, that Republican Rome provides contemporary societies with a model of how civic deliberation could manage and resolve social conflict. ${ }^{5}$ And in his Roman social imaginaries, Clifford Ando explores the ways in which the emerging definition of the res publica in Roman law of the Republican period created the conditions for the spread of Roman power. ${ }^{6}$ 
Ando talks of 'the highly abstract homologies... in Roman toleration' that 'served to sustain substantial political, social, and material realities of difference'. ${ }^{7}$ Citizenship is a key example of such a homology, and this emptying citizenship of ethnic or even geographical content, Ando argues, was key to the creation of a system of citizenship that eventually allowed Rome, in the third century AD, to make all free inhabitants of its empire citizens. Connolly's focus on political participation leads her to acknowledge that the spread of citizenship beyond Rome radically altered the dynamics of citystate politics. She explores the ways in which this change drove the development of Roman political theory: not simply in the decoupling of citizenship from ethnicity and the replacement of the idea of kinship with that of behaviour within a legally defined community, but also in the focus in some writers, particularly Sallust, on the conditions necessary for equality between citizens, and his exploration of whether legal equality can be effective without some form of economic equality.

These are powerful and important claims: that it is possible to create a global citizenship that gives its owners access to a shared legal and political system without overwriting local identities or imposing a single set of cultural norms. My purpose in this paper is to argue that, powerful and important though the claims are, they do not fully capture the complexity of Roman citizenship, or its weaknesses. Roman citizenship, I argue, was fundamentally about Roman military power and its capacity to dominate other communities. Roman generosity with citizenship, an inclusiveness that was exceptional among ancient communities and recognised by contemporaries as such, was an aspect of the process by which Rome moved, between the third and first centuries BC, from being a regional power in central Italy to the ruler of a Mediterranean empire. Through the same period, the failure of Rome's governing class to engage with the practical implications of a broad-based citizenship was a major contributing factor in their loss of control of a political system that involved mass political participation and the subsequent emergence of a monarch whose power was based on control of an army. Rome was a political community in which tensions between the political and legal aspects of citizenship were never satisfactorily resolved, and it was only when citizenship ceased to involve political participation that it could operate peacefully as a unifying cultural and economic force. 


\section{Acquisition and transmission of citizenship}

How did one become a Roman citizen? The simplest method was to be born a citizen, which in Roman law was to be born the child of a citizen mother. ${ }^{8}$ This meant that citizen males could only produce citizen children within a legal marriage. However, this framework should be considered as a set of enabling conditions, rather than automatic authorisors of citizen status: the process of becoming a citizen in the sense of taking on its active functions was not only age-dependent but also involved ceremonial markers of the transition from childhood to adulthood. Thus, Roman males became adults through the completion of a publicly observed ceremony that acknowledged their transition from childhood to adulthood. Nonetheless, there is little to suggest that boys failed to make this transition: once a newborn child of citizen parents had been accepted by its family as worthy of rearing, he or she was on a trajectory towards acceptance by the community as a citizen him- or herself.

Where Rome differed significantly from most ancient city-states was in the extent to which it made citizens out of people who had not been born as Romans. One route by which this took place was through the enfranchisement of slaves. Within Roman law, slave owners could free their slaves; and freed slaves took the status of their former owner. Moreover, this citizen status was inheritable on the same terms as for those born eligible to be citizens; thus, the children of freedmen and freedwomen who were married to citizens (free or freed) would themselves become citizens. (Various restrictions on the use of citizen status among freed slaves were not transmitted to their offspring. $)^{9}$ As Rome became a major slave society as a result of its military conquests in the second century $\mathrm{BC}$, growth in the citizen population through enfranchisement became a significant element in overall population growth. ${ }^{10}$ A striking example is the dictator Sulla's simultaneous mass enfranchisement of young male slaves drawn from the estates of those who had been judicially murdered during the proscriptions of 82-81 вс. ${ }^{11}$

A second significant driver of enfranchisement was the bestowal of citizen status upon entire non-Roman communities. From the fourth century BC onwards, a series of non-Roman city-states across Italy received grants of Roman citizenship: their inhabitants ceased to have separate juridical identities based on belonging to the political community where they lived. The process began with grants of full citizenship to a number of communities geographically close to 
Rome that were also Latin speaking, but eventually applied to places in central Italy considerably more distant from Rome. ${ }^{12}$ An excellent example is the town of Arpinum, nearly 60 miles from Rome, which became a Roman community in $188 \mathrm{BC}$ : that its citizens became citizens of Rome is an evident challenge to the idea of a city-state. ${ }^{13}$ Moreover, inhabitants of municipia, that is urban communities that had acquired Roman citizenship, continued to possess a civic identity related to their municipal home, as Cicero's two patriae indicate; and had the opportunity to participate in a local political culture, including the election of magistrates. ${ }^{14}$ Yet legally, free inhabitants of Arpinum were Roman citizens who simply happened not to live in Rome.

Alongside the enfranchisement as Romans of existing non-Roman communities was the creation of new communities of Roman citizens as coloniae, colonies. This process of Roman colonisation of Italy was the product of Roman military victory, starting with the foundation of a colony at Antium, along the coast south of Rome, in 338 BC, the same year Aricia, Lanuvium and other Latin-speaking communities in the vicinity of Rome became communities of Roman citizens. Antium was only 30 miles from Rome, but the device of the Roman citizen colony was eventually extended across Italy. Citizen colonies were established deep in southern Italy, as distant as Croton and north of the Appennines, as Rome extended its power into the Po valley. These settlements evidently had a military purpose and, at least until the end of the Republic, they had only limited self-government: various anecdotes suggest that Roman magistrates had no hesitation in directly intervening in their activities as and when needed, and usually in response to some military requirement. ${ }^{15}$

A further complicating factor in the Republican period was the parallel existence of various relationships between Rome and the other Latin-speaking communities guaranteeing rights of settlement, intermarriage and contract, and allowing for the prospect of change of citizenship to follow change of habitation from one community to another. These 'Latin rights' were reciprocal between all the Latin communities, including Rome, though as Rome became pre-eminent among them the point of interest was chiefly in the rights of non-Roman Latins to access Roman civic and legal space, and in the use of the 'Latin right' as a tool of government. Rome decided that it could create a category of Latin status, divorced from existing Latin communities, and apply that status to newly-founded colonies. Thus, Latin colonies existed alongside Roman ones, without necessarily any 
clear strategic distinction between the two; so in 183 вС the Roman Senate had difficulty in deciding whether the colonial foundation at Aquileia that it had in mind should be settled as a Roman or a Latin colony. ${ }^{16}$

Finally, there was the status of ciuitas sine suffragio, 'citizenship without the vote', which was given to some communities that had been allies of Rome in Campania. The ciuitas involved was Roman, not Latin-but this status did not involve the ending of the community's self-government. Rather, it seems to have been driven by military rather than civil concerns: the inhabitants of these communities were liable for service in the Roman legions, rather than its allied forces, and also lost their ability to conduct an independent foreign policy, which might, for example, involve attacking Rome's allies. Thus, ciuitas sine suffragio was a way for Rome to maintain its control of another community without interfering with its internal organisation. ${ }^{17}$

It is evident from even this brief sketch that Roman citizenship was a phenomenon that had evolved alongside Rome's developing power within Italy, as one among a number of ways in which Rome organised its relations with other communities. There was no single driver of the process: political, military and legal considerations all played a part in creating a patchwork of statuses that can appear to defy rational explanation, and that clearly on occasion left some Romans confused. The combination of legal exactitude over the definition of the rights of a citizen, with political pragmatism over the use of citizenship to articulate power, is striking. When Rome made non-Roman communities Roman, it did so as a result of military conquest and in order to manifest its power. This process operated both symbolically and practically: the pre-existing independent polity was obliterated and its manpower resources were now assessed through the Roman census and available to serve in the Roman army. It is important to remember that in the mid-Republic Roman citizenship was not invariably welcomed by the communities that received it. Livy records the settlement in 306 BC between Rome and the Hernici in central Italy after a war in which the Romans had been victorious. Some of the communities among the Hernici had not joined in the campaign and at the end of the conflict these were offered Roman citizenship but declined it: 'they were permitted, because they preferred it, to have back their own laws and to enjoy intermarriage between their communities'. ${ }^{18}$ They were later used by the Aequi as an exemplum to demonstrate that 'for those who did not have the opportunity to choose, forced citizenship was a 
punishment'. ${ }^{19}$ And the point of interest here is not only that Roman citizenship might be declined but that the very opportunity to decline it was dependent upon Roman willingness to grant that opportunity. What marks Rome out from other ancient city-states here is not a pacific inclusiveness but rather a highly creative use of legal possibilities to extend its power.

In this context, it is important to bear in mind that the enfranchisement of individuals who were not former slaves remained exceptionally unusual until the very end of the Republican period. Most of the few securely attested incidents involved a Roman military commander giving Roman citizenship as an honorific gesture, usually to allied troops under his command, or were driven by other public imperatives (though we also note the enfranchisement by Pompeius of the Greek historian Theophanes, who accompanied him in his campaign against Mithridates of Pontus). ${ }^{20}$ It is evident that dual citizenship when one of the statuses was Roman was highly contentious from a legal perspective until the end of the Republic. This is the basis of the argument that Cicero made in a speech he gave in 56 BC in defence of L. Cornelius Balbus. Balbus, from Gades in Spain, who had been made a Roman citizen by Pompeius during the latter's campaigns in Spain in the 70 s BC, was accused of falsely claiming to be a citizen. ${ }^{21}$ The Balbus case reveals the extent to which the enfranchisement of individuals provoked unease: it seems highly likely that Balbus was attacked as a way of embarrassing his Roman patrons by forcing them to defend a non-Roman intimate. ${ }^{22}$ Indeed, it has been argued that one of the ways that Caesar sought to differentiate himself from Pompeius was by emphasising Roman identity over Pompeius' Hellenistic cosmopolitanism, and that this was also reflected in Caesar's choice of intimate associates. ${ }^{23}$ There was no geographical content to citizenship after the early Republic, and the converse was also true: there was no community-enforced geographical restriction on non-citizens. Anyone could live in Rome. But for those inhabitants who were not citizens but were free, residence in Rome, even if extended over generations, brought with it absolutely no opportunity to access citizenship.

\section{Citizenship and participation}

The lived experience of citizenship varied in ways that followed from but were not entirely dictated by an individual's status. Rather, status 
combined with geography and wealth to offer gradations of participation. So, a Roman citizen living in Rome had, in theory, access to the full range of legal and political privileges attached to the status: he conducted his personal affairs within the framework of Roman law and could exercise his political rights as a citizen by voting in elections and on legislative proposals. A Roman citizen living at Croton had access to an identical legal framework, but very little opportunity to participate in the political life of Rome; much less than a citizen of a Latin community who happened to live in Rome and as a result could vote in some, though not all, citizen assemblies. Moreover, political participation in Rome-in distinction to legal rights within the civil law-was highly stratified: not all citizens were equal. Rome did not have a 'one man, one vote' system; men voted within larger units, with the result - whether through election of magistrates or passage of laws - depending on the aggregation of voting units, not the absolute number of votes. Thus, the result depended on the size of the unit in which a man voted, and it is evident that these varied considerably, with the wealthy voting in much smaller units than the poor. This bias towards wealth was probably compounded by geographical factors, as citizens who lived outside Rome voted in different units from inhabitants of Rome, and it seems reasonable to expect that, insofar as any of those who lived outside Rome did participate in its political processes, those with resources were over-represented among those travelling to Rome. ${ }^{24}$

This differential access to political power as it was exercised in Rome sat alongside differential access to power across Italy. Roman citizenship was a phenomenon that had evolved alongside Rome's developing power within Italy, as one of a number of ways in which Rome organised its relations with other communities. There was no single driver of the process: political, military and legal considerations all played a part in creating a patchwork which placed non-Roman territory next to Roman territory; and which can appear to defy rational explanation. From a Romanocentric perspective, Roman citizenship appears to be a good that others will naturally seek to acquire. And yet, as we have seen, not all communities wanted to become Romans; nor should we assume that all members of a particular community incorporated into Rome reacted to the prospect identically.

The contrast between Roman and non-Roman statuses in Italy became an urgent political problem at the end of the second century $\mathrm{BC}$, as tensions rose between Rome and the rest of Italy. In 125 вC the 
Latin community of Fregellae rebelled from Rome (in a time of absolute peace within sub-Appennine Italy); it was defeated, and Rome then destroyed the physical town, including its large sanctuary to Asclepius, and founded a new town nearby. The causes of this episode are difficult to explain satisfactorily but wider tensions can be discerned which probably derive from or at least were exacerbated by Tiberius Gracchus' land legislation in 133 вс. By authorising the redistribution of ager publicus-land that Rome had seized during its conquest of Italy and now held as state property, leased to individuals-Tiberius' land-surveyors, who were remarking the boundaries of ager publicus, almost certainly came into conflict with non-Roman communities over the precise boundary lines. Individually these episodes may have been trivial, but collectively they will have brought home to non-Roman communities their powerlessness to directly affect Roman decision making.

The precise stages of the deterioration between Romeand non-Roman Italy over the next 40 years are impossible to trace, though there are certain striking episodes (such as the expulsion of non-Romans from Rome in $95 \mathrm{BC}$ ). What is clear, though, is that an internal crisis at Rome in $91 \mathrm{BC}$, which ultimately derived from as apparently insignificant a matter as the composition of juries, and which threatened further encroachment on non-Roman communities' autonomy, was the final straw. Non-Roman Italy organised its manifold different communities into a single federal state and took on Roman power. The war that followed, the so-called Social War, lasted three years and, according to the early imperial historian Velleius, killed 300,000 combatants. The Romans themselves presented it as a victory, but its conclusion was certainly hastened by a series of emergency legislative measures that offered Roman citizenship to various communities, initially to prevent further defections and then as a means towards peace. Whether the rest of Italy went into the war with the intention of getting Roman citizenship (as opposed to reshaping the nature of Rome's power within Italy) remains hotly contested. ${ }^{25}$ But setting that question aside, extending the citizenship was a transformative moment for Roman power.

First, the process of enfranchisement was slow, piecemeal, and apparently lacked any central oversight. It very much smacks of emergency decision-making, as the Senate grasped at any means that might save it from military disaster. (The death rate among senior commanders in the first two years of the Social War on the Roman side was 
extraordinarily high - it can barely be matched even by the most challenging years of the second Punic war.) It did not lead to any change in internal processes at Rome; the exercise of citizen rights could only take place in Rome, and the process of registering citizens still depended on a census conducted in Rome. (The process of conducting the census in these new circumstances must have involved some delegation, but the first full census was not until $70 \mathrm{BC}$; it is far from clear that the new citizens could participate fully in political processes before that date). There were colossal internal squabbles in Rome over the way in which new citizens would be registered. This reflects a sense of the uncontrollability of the new citizen body, which contributed to the instability of political life after the extension of the franchise. There was widespread cash bribery and an increasing trend for elections to be postponed, as individuals attempted to manipulate the composition of the voting body that would actually be present at the election.

This instability, which played a key role in the ending of the Republic in a series of civil wars, arose because the Roman governing elite was unable to find a way of accommodating the participatory aspect of citizenship as it had developed before the Social War. In part this was due to a failure of nerve over what was regarded as a zero-sum game: if the goods to which citizenship gave access were finite, the extension of citizenship reduced each individual citizen's benefit from that status. ${ }^{26}$ The only method of evading the subsequent unpopularity was to harness the support of new citizens; so a further factor that hampered a rational allocation of new citizens to voting units was the collective fear within the Senate that one of its members would gain extraordinary personal acclaim and power by championing the rights of new citizens. But even had the Roman Senate and people adopted more statesmanlike solutions, they faced the more intractable problem of participation and distance. Citizens living across Italy simply could not participate in political life at Rome, if participation depended on physical presence. Yet Rome consistently did not recognise this as a problem, from the creation of its first citizen colonies onwards. I would suggest that that was not simply the result of a failure of creative imagination; rather, citizenship as a question of legal status, which demanded uniformity, overruled citizenship as a matter of participation, which would in turn have suggested differentiated forms of political participation within a federal system, of which there were examples in antiquity. 
This tension was released once Rome became a monarchy, since citizen participation in politics came to an end. There continued to be advantages in living in Rome as a citizen, but these were material benefits which added to the stratification of Roman society by economic and legal status. A peaceful, empire-wide community of citizens enjoying a defined legal status regardless of their ethnic or cultural identity became possible, at Rome at least, only after citizenship had been emptied of its political significance.

\section{Notes}

${ }^{1}$ On Roman citizenship, the fundamental guide in English remains A.N. Sherwin-White, The Roman citizenship (Oxford, 1973, 2nd edn).

${ }^{2}$ On the extension of Roman citizenship in AD 212 through the constitutio Antoniniana, see Kostas Buraselis, OEIA $\triangle \Omega P E A$ : das göttliche-kaiserliche Geschenk. Studien zur Politik der Severer und zur Constitutio Antoniana (Vienna, 2007); C. Ando (ed.), Citizenship and empire in Europe, 200-1900: the Antonine Constitution after 1800 years (Stuttgart, 2016).

${ }^{3}$ On Rome's foundation myths, see Gary B. Miles, Livy: reconstructing early Rome (Ithaca, 1995); R. Brown, 'Livy's Sabine women and the ideal of concordia', Transactions of the American Philological Association 125 (1995), 291-319.

${ }^{4}$ Inscriptiones Graecae IX 2, 517, lines 32-34, as translated from the Ancient Greek:

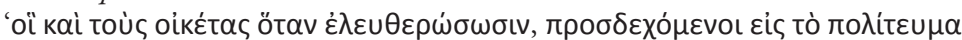

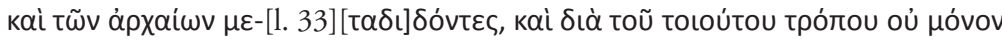

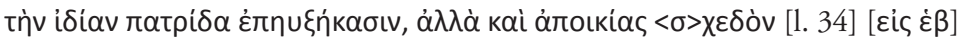

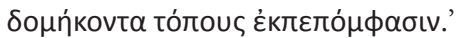

5 Joy Connolly, The state of speech: rhetoric and political thought in Ancient Rome (Princeton, 2007); Joy Connolly, The life of Roman republicanism (Princeton, 2015).

${ }^{6}$ Clifford Ando, Roman social imaginaries: language and thought in contexts of empire (Toronto, 2015), 7-28.

7 Ando, Roman social imaginaries, 96.

8 John Crook, Law and life of Rome (London, 1967), 36-67.

9 On manumission, see Alan Watson, Roman slave law (Baltimore, 2007); 23-34; Henrik Mouritsen, The freedman in the Roman world (Cambridge, 2011) 120-205.

${ }^{10}$ Keith Hopkins, Conquerors and slaves (Cambridge, 1978) 1-132; Walter Scheidel, 'Human mobility in Italy II: the slave population', Journal of Roman Studies 95 (2005), 64-79.

\section{${ }^{11}$ App. BC 1. 100.6}

${ }_{12}$ Sherwin-White, The Roman citizenship, 58-76; Edward Bispham, From Asculum to Actium: the municipalization of Italy from the Social War to Augustus (Oxford, 2007), 52-73.

13 Arpinum was Cicero's home town; in his dialogue De Legibus (2. 2. 5), written in the late 50s BC, the character Atticus asks whether the character Cicero does not have two patriae (fatherlands), to which the character Cicero responds, 'I certainly do 
believe that he [sc. the elder Cato] and every man of municipal origin has two fatherlands, one by nature and the other by citizenship' (ego mehercule et illi et omnibus municipibus duas esse censeo patrias, unam naturae, alteram ciuitatis).

${ }_{14}$ Cicero's grandfather was commended by the Roman politican Scaurus for his resistance to the introduction of the secret ballot to Arpinum (Cic. De Leg. 3. 36). See further the discussion in Bispham, From Asculum to Actium, 74-112.

15 Sherwin-White, The Roman citizenship, 76-94.

${ }_{16}$ Livy 39. 55. 5.

17 Sherwin-White, The Roman citizenship, 39-58; Bispham, From Asculum to Actium, $16-31$.

${ }_{18}$ Livy 9. 43. 23, quia maluerunt quam ciuitatem, suae leges redditae conubiumque inter ipsos. ... permissum.

${ }_{19}$ Livy 9. 45. 8, quibus legendi quid mallent copia non fuerit, pro poena necessariam ciuitatem fore.

${ }^{20}$ Sherwin-White, The Roman citizenship, 291-96; Henrik Mouritsen, Italian unification: a study in ancient and modern historiography (London, 1998), 87-92; Altay Coşkun, 'Civitas Romana and the inclusion of strangers in the Roman Republic: the case of the Civil War', in A. Gestrich, L. Raphael and H. Uerlings (eds), Strangers and poor people: changing patterns of inclusion and exclusion in Europe and the Mediterranean world from classical antiquity to the present day

(New York, 2009), 135-64; on bestowal of citizenship and religious practice, Elena Isayev, 'Just the right amount of priestly foreignness: Roman citizenship for the Greek priestess of Ceres', in J. Richardson and F. Santangelo (eds), Priests and state in the Roman world (Stuttgart, 2011), 373-90.

${ }^{21}$ Peter Brunt, 'The legal issue in Cicero Pro Balbo', Classical Quarterly 32 (1) (1982), 136-47.

22 Catherine Steel, Cicero: rhetoric and empire (Oxford, 2001), 107-110.

${ }^{23}$ L. Hall, 'Ratio and Romanitas in the Bellum Gallicum' in K. Welch and

A. Powell, Julius Caesar as artful reporter: the war commentaries as political instruments (Swansea, 1998), 11-43: 22-29.

${ }^{24}$ Lily Ross Taylor, The voting districts of the Roman Republic: the thirty-five urban and rural tribes (Rome, 1960).

${ }^{25}$ Mouritsen, Italian unification, 109-75; Bispham, From Asculum to Actium, $161-204$.

${ }^{26}$ As a fragment of a speech given by Gaius Fannius in 122 BC, in opposition to a proposal to extend citizenship to those of Latin status, indicates clearly: 'If you were to give citizenship to the Latins, I believe, you reckon that you will take up your position in the contio, as you are standing assembled now, and that you will take part in the games and festivals. Do you not think that those people will take over everything?' (si Latinis ciuitatem dederitis, credo, existimatis uos ita, ut nunc constitistis, in contione habituros locum aut ludis et festis diebus interfuturos. nonne illos omnia occupaturos putastis?). The quotation is preserved in Iulius Victor, Ars Rhet. 6. 4. 